Пархоменко-Куцевіл Оксана Ігорівна доктор наук 3 державного управління, професор, завідувач кафедри публічного управління та адміністрування, Університет Григорія Скоровороди в Переяславі, вул. Сухомлинського, 30, Переяслав, 08400, тел.: (050) 922-15-35, e-mail: pkoi@ukr.net, https://orcid.org/0000-0002-0758-346X

\title{
КОНЦЕПТУАЛЬНІ ЗАСАДИ ФОРМУВАННЯ ПОДАТКОВОЇ БЕЗПЕКИ В СИСТЕМІ НАЦІОНАЛЬНОЇ БЕЗПЕКИ УКРАЇНИ
}

Анотація. У статті обгрунтовано, що сутність економічної безпеки в системі національної безпеки можна визначити як такий стан економіки та інститутів влади, при якому забезпечується гарантований захист національних інтересів, соціально спрямований розвиток країни в цілому, достатній оборонний потенціал при найбільш несприятливих умовах розвитку внутрішніх і зовнішніх процесів.

Податкова безпека $\epsilon$ одним 3 головних елементів національної та економічної безпеки. Це можна пояснити самою сутністю податків, адже вони основний спосіб поповнення державного бюджету. Крім того, податки виступають фінансовими засобами для виконання функцій держави.

Обгрунтовано, що можна виокремити наступні концептуальні засади формування та забезпечення податкової безпеки в системі національної безпеки: ефективність нормативно-правових засад формування та розвитку податкової безпеки; інституційна спроможність органів державної влади та місцевого самоврядування забезпечувати податкову безпеку та спеціально уповноваженого підрозділу для виконання таких функцій; професіоналізація та розвиток кадрів, які працюють в податковій системі; модернізація системи оподаткування з метою забезпечення податкової безпеки; комплексна діагностика, головною метою якої $\epsilon$ визначення рівня податкової безпеки.

Запропоновано у складі Бюро економічної безпеки України слід запровадити діяльність Департаменту із забезпечення податкової безпеки. До основних завдань Департаменту із забезпечення податкової безпеки слід віднести, зокрема: виявлення ризиків у сфері податкової безпеки; оцінювання сучасного законодавства 3 точки зору виникнення внутрішніх небезпек для податкової безпеки; аналіз сучасного світового досвіду забезпечення податкової безпеки та імплементація кращих практик у національне законодавство; забезпечення податкової безпеки держави шляхом запобігання, виявлення, припинення, розслідування кримінальних правопорушень, що посягають на функціонування податкової системи; збирання та аналіз інформації про правопорушення, що впливають на податкову безпеку держави, та визначення способів запобігання їх 
виникненню в майбутньому; планування заходів у сфері протидії кримінальним правопорушенням, віднесеним законом до його підслідності; виявлення та розслідування правопорушень, пов'язаних 3 отриманням та використанням міжнародної технічної допомоги та ін.

Ключові слова: податкова безпека, національна безпека, ризики податкової безпеки, професіоналізація кадрів, оцінювання ризиків.

Parkhomenko-Kutsevil Oksana Ihorivna Doctor of State Administration, Professor, Head of the Department of Public Administration and Administration, Hryhorii Skovoroda University in Pereiaslav, Sukhomlinskoho St., 30, Pereyaslav, 08400, tel.: 050) 922-15-35, e-mail: pkoi@ukr.net, https://orcid.org/0000-0002-0758-346X

\section{CONCEPTUAL PRINCIPLES OF TAX SECURITY FORMATION IN THE NATIONAL SECURITY SYSTEM OF UKRAINE}

Abstract. The article substantiates that the essence of economic security in the national security system can be defined as a state of economy and institutions of power, which provides guaranteed protection of national interests, socially oriented development of the country as a whole, sufficient defense potential under the most unfavorable conditions of internal and external processes.

Tax security is one of the main elements of national and economic security. This can be explained by the very essence of taxes, because they are the main way to replenish the state budget. In addition, taxes are financial means to perform state functions.

The author substantiates that the following conceptual bases of formation and maintenance of tax security in the system of national security can be distinguished: efficiency of normative-legal bases of formation and development of tax security; the institutional capacity of public authorities and local governments to ensure tax security and a specially authorized unit to perform such functions; professionalization and development of personnel working in the tax system; modernization of the taxation system in order to ensure tax security; comprehensive diagnostics, the main purpose of which is to determine the level of tax security.

The article proposes that the activities of the Department for Tax Security should be introduced within the Bureau of Economic Security of Ukraine. The main tasks of the Department of Tax Security should include, in particular: identification of risks in the field of tax security; assessment of modern legislation in terms of internal threats to tax security; analysis of modern world experience in ensuring tax security and implementation of best practices in national legislation; ensuring the tax security of the state by preventing, detecting, stopping, investigating criminal offenses that encroach on the functioning of the tax system; collecting and analyzing information on offenses that affect the tax security of the state, and identifying ways to prevent their occurrence in the future; planning of measures in the field of counteraction to the criminal offense

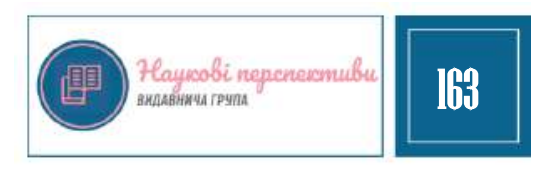


carried by law to its jurisdiction; detection and investigation of offenses related to the receipt and use of international technical assistance, etc.

Keywords: tax security, national security, tax security risks, personnel professionalization, risk assessment.

Постановка проблеми. На сьогодні питання підвищення прибутковості бюджетів, а саме, зростання податкових надходжень за рахунок вдосконалення оподаткування є актуальними. Це питання аналізують як економісти, так і фахівці з державного управління, соціології, правознавства.

3 процесом управління оподаткуванням нерозривно пов'язана податкова безпека, тобто, чим вище рівень ефективності податкового адміністрування, тим нижче у держави загроз у зв'язку з недоотриманням фінансових ресурсів.

Податкову безпеку держави прийнято розглядати і оцінювати через призму якості податкового адміністрування, яке $\epsilon$ індикатором стану податкової системи, iii ефективності. Важливо відзначити, що заходи економічної безпеки країни займають провідне місце в податковому адмініструванні.

Органи виконавчої влади, які здійснюють податкове адміністрування, $\epsilon$ суб'єктами забезпечення податкової безпеки України, яка знаходиться під загрозою, якщо допускається непрофесійний підхід, відсутність застосування належної правової процедури в податкових правовідносинах. Це знижує стабільний розвиток економіки і поліпшення добробуту населення.

Аналіз останніх досліджень і публікацій. Проблему податкової безпеки часто аналізують як основу економічної безпеки, зокрема: О. Барановський, Ю. Бережна, В. Білостоцька, С. Голіков, В. Іщенко, В. Задорожна, В. Мартинюк, Ю. Полянська, А. Соколовька, І. Тимофєєв, Д. Тихонов та ін. Так, Економічний аспект податкової безпеки полягає у ступені наповненості бюджету фінансовими ресурсами, на який впливає низка факторів: рівень розвитку економіки, приріст валового внутрішнього продукту, рівень інфляції, податкове навантаження на суб'єктів економіки, що залучені у відтворенні [1].

Проблема врегулювання податкової безпеки в Україні, організаційної побудови податкової системи, здійснення податкової діяльності серед юристів займалися такі вчені, як С. Адонін, В. Білоус, О. Бандурко, О. Добровольський, Ю. Іванов, І. Луценко, І. Скороход, А. Чубенко, І. Цимбалюк і багато інших. Зазначені вчені звертали увагу на вивчення теорії права й аналізу чинного законодавства щодо особливостей сучасної податкової безпеки України.

Однак, на даний час відсутні системні дослідження проблем концептуальних засад формування податкової безпеки в системі національної безпеки України як основи державного управління.

Мета статті - системний аналіз концептуальних засад формування податкової безпеки в системі національної безпеки України як основи державного управління. 
Виклад основного матеріалу. На початку дослідження 3'ясуємо сутність поняття «податкова безпека в системі національної безпеки України». Так, податкова безпека це:

- такий стан податкової сфери держави, для якого характерним є захищеність інтересів суб'єктів податкових відносин, стійкість і економічна незалежність податкової системи, що проявляється у стабільності податкового законодавства; здатність податкової системи до розвитку i вдосконалення, спроможність своєчасного виявлення та запобігання потенційних загроз у сфері оподаткування та здатність системи оподаткування в повній мірі реалізовувати усі функції податків як фіскальної так і регулюючої та соціальної з метою максимального узгодження інтересів держави та платників податків [2, с.13-23];

- частина фінансової безпеки держави, яка визначається наявністю сформованої податкової системи, оптимальним рівнем оподаткування, що забезпечує достатнє наповнення за рахунок податкових надходжень дохідної частини бюджету для виконання державою своїх функцій, а також забезпечує розвиток реального сектору економіки та соціальний захист населення [3, с. 39-40];

- підсистема національної безпеки держави, яка являє собою стан податкової системи, за якого забезпечується гарантований захист і гармонійний розвиток всієї податкової системи держави, можливість податкових інструментів захищати національні інтереси держави, підтримувати соціально-економічну стабільність суспільства, а також формувати достатньо фінансових ресурсів для держави i місцевого управління, успішне протистояння існуючим загрозам податкової системи [4, с.32];

- інтегрована підсистема економічної безпеки, яка впливає на фінансове забезпечення всіх ऑii складових: інноваційнотехнологічної, інвестиційної, енергетичної, сировинно-ресурсної, продовольчої, соціальної, експортної, імпортної та міжнародноінтеграційної безпеки [5, с. 9-11].

Таким чином, сутність економічної безпеки в системі національної безпеки можна визначити як такий стан економіки та інститутів влади, при якому забезпечується гарантований захист національних інтересів, соціально спрямований розвиток країни в цілому, достатній оборонний потенціал при найбільш несприятливих умовах розвитку внутрішніх і зовнішніх процесів.

Податкова безпека $\epsilon$ одним 3 головних елементів національної та економічної безпеки. Це можна пояснити самою сутністю податків, адже вони основний спосіб поповнення державного бюджету. Крім того, податки виступають фінансовими засобами для виконання функцій держави.

Проведений аналіз дає підстави зазначити, що сутність концепції податкової безпеки розкривають такі взаємопов'язані елементи: по-перше, питання теорії забезпечення податкової безпеки; по-друге, питання оптимізації податкової політики держави як важливого елементу національної безпеки України; потретє, питання формування інституційної спроможності органів державної влади та органів місцевого самоврядування; по-четверте, формування дієвої

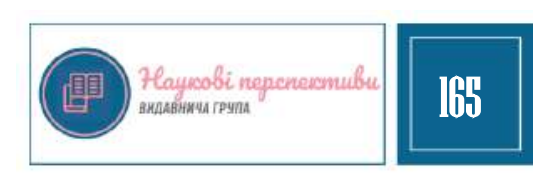


антикорупційної політики як основи податкової безпеки України; по-п’яте, формування ефективної державної кадрової політики в частині професіоналізації кадрів системи податкової безпеки.

Захищеність національних інтересів забезпечується готовністю і здатністю інститутів влади створювати механізми реалізації та захисту національних інтересів розвитку вітчизняної економіки, підтримки соціально-політичної стабільності суспільства.

Нормативно-правовими засадами формування та розвитку податкової безпеки як частини національної безпеки є: Податковий кодекс Україні, який регулює відносини, що виникають у сфері справляння податків і зборів, зокрема визначає вичерпний перелік податків та зборів, що справляються в Україні, та порядок їх адміністрування, платників податків та зборів, їх права та обов'язки, компетенцію контролюючих органів, повноваження і обов'язки їх посадових осіб під час адміністрування податків та зборів, а також відповідальність за порушення податкового законодавства [6], закони України, що регулюють сплату окремих видів податків, підзаконні акти.

Окремо слід звернути увагу на Закон України «Про внесення змін до Податкового кодексу України та інших законів України щодо стимулювання детінізації доходів та підвищення податкової культури громадян шляхом запровадження одноразового (спеціального) добровільного декларування фізичними особами належних їм активів та сплати одноразового збору до бюджету», метою якого є запровадити механізм податкової амністії. Цілей у податкової амністії декілька. Бізнесмени та інші заможні українці розглядають можливості запропонованої податкової амністії більше 3 метою фіксування обсягу своїх активів на даний конкретний момент 3 тим, щоб рухатися далі в процесі інвестування або накопичення. У світлі глобальної прозорості і боротьби 3 ухиленням від оподаткування, податкова індульгенція виглядає вельми привабливим документом для співробітництва 3 банками та фінансовоінвестиційними компаніями [7]. Водночас, саме цей закон може нести проблеми щодо забезпечення податкової безпеки через узаконення статків, отриманих злочинним шляхом.

Існування безлічі законодавчих актів разом з базовим Податковим кодексом України створює проблеми із застосування таких нормативно-правових норм, ускладнює розуміння сучасної моделі оподаткування в Україні, надає можливості деяким особам (юридичним особам) зловживати становищем та ухилятися від сплати податків, розвивати тіньову економіку. Саме прозора система урегулювання податкової безпеки повинна створити підвалити відповідної захищеності держави від ризиків та небезпек. Крім того, складність нормативноправового регулювання системи оподаткування дає можливість узаконювати нелегальні доходи та доходи, отримані від корупції.

На нашу думку, на сьогодні виникла об’єктивна потреба у розробці нормативно-правового акту щодо забезпечення податкової безпеки. Це може 
бути, зокрема Стратегія забезпечення податкової безпеки, на підставі якої передбачити розробку системного єдиного документу у галузі оподаткування, зокрема, Кодексу формування та забезпечення податкової безпеки в Україні.

Наступний елемент податкової безпеки є інституційна спроможність органів державної влади та місцевого самоврядування забезпечувати податкову безпеку держави. Так, відповідно до Закону України «Про Бюро економічної безпеки України» Бюро економічної безпеки України - це центральний орган виконавчої влади, на який покладаються завдання щодо протидії правопорушенням, що посягають на функціонування економіки держави [8]. Саме у складі згаданого бюро слід запровадити діяльність Департаменту із забезпечення податкової безпеки.

До основних завдань Департаменту із забезпечення податкової безпеки слід віднести, зокрема:

1) виявлення ризиків у сфері податкової безпеки;

2) оцінювання сучасного законодавства з точки зору виникнення внутрішніх небезпек для податкової безпеки;

3) аналіз сучасного світового досвіду забезпечення податкової безпеки та імплементація кращих практик у національне законодавство;

4) забезпечення податкової безпеки держави шляхом запобігання, виявлення, припинення, розслідування кримінальних правопорушень, що посягають на функціонування податкової системи;

5) збирання та аналіз інформації про правопорушення, що впливають на податкову безпеку держави, та визначення способів запобігання їх виникненню в майбутньому;

6) планування заходів у сфері протидії кримінальним правопорушенням, віднесеним законом до його підслідності;

7) виявлення та розслідування правопорушень, пов’язаних з отриманням та використанням міжнародної технічної допомоги та ін.

Саме такий орган державної влади буде не тільки забезпечувати податкову безпеку України, а й прораховувати ризики та небезпеки для податкової безпеки, аналізувати проекти нормативно-правових документів 3 точки зору їх відповідності засадами податкової безпеки та надавати відповідне правове обгрунтування.

Ще одним елементом податкової безпеки - це професійні кадри, які працюють в податковій системі. Тому потрібно створити спеціальні освітні програми, спрямовані на підготовку саме кадрів в системі податкової безпеки держави, передбачивши професійне стажування в Україні та за кордоном, постійне підвищення кваліфікації таких кадрів.

Говорячи про податкову безпеки, необхідно розглянути також питання іiі комплексної діагностики, головною метою якої $є$ визначення рівня податкової безпеки. Водночас, якість здійснення діагностики залежить від правильності методологічних підходів і тактичних прийомів. Діагностика податкової безпеки

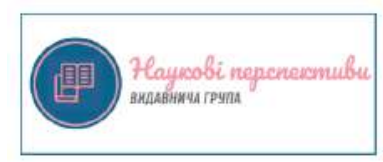


може мати різні форми: комплексна (аналіз основних податкових показників за всіма видами податків в цілях виявлення податкових загроз); функціональна (аналіз окремого елемента оподаткування і прийняття точкового рішення для підвищення ефективності конкретного напряму); експрес-діагностика (встановлення причини і термінове рішення податкової проблеми) тощо.

Важливою проблемою щодо забезпечення податкової безпеки є модернізація системи оподаткування. Основний акцент необхідно зробити на впровадженні сучасних технологій, вдосконаленні організаційної структури податкових органів i підвищення кваліфікації співробітників, застосування новітніх алгоритмів i методик податкових перевірок, оптимізації процесу обробки даних, проведення своєчасного податкового аналізу. Все це дозволить підвищити якість управління податковими витратами, крім того сприятиме оперативному виявленню та попередженню порушень пов'язаних зі сплатою податкових платежів.

Крім того, важливим концептуальним елементом податкової безпеки в системі національної безпеки є дієві заходи подолання корупції, мінімізації проявів корупції. Корупція не лише наносить шкоду національній безпеці держави, вона погіршує добробут населення, зменшує привабливість України для іноземних інвесторів, погіршує міжнародний імідж нашої країни. Саме формування податкової безпеки є основою розвитку України та економічного добробуту.

Проведений аналіз дає підстави виокремити наступні концептуальні засади формування та забезпечення податкової безпеки в системі національної безпеки:

- ефективність нормативно-правових засад формування та розвитку податкової безпеки;

- інституційна спроможність органів державної влади та місцевого самоврядування забезпечувати податкову безпеку та спеціально уповноваженого підрозділу для виконання таких функцій;

- професіоналізація та розвиток кадрів, які працюють в податковій системі;

- модернізація системи оподаткування 3 метою забезпечення податкової безпеки;

- комплексна діагностика, головною метою якої $\epsilon$ визначення рівня податкової безпеки;

- формування дієвих заходів подолання корупції, мінімізації проявів корупції.

Висновки. Слід зазначити, що вплив податків на економічну та національну безпеку України неоднозначний. 3 одного боку вони виступають основним ресурсом забезпечення економічної та національної безпеки, а з іншого боку фактором ряду ризиків і загроз національній та економічній безпеці. Автором були виокремленні концептуальні засади формування та забезпечення податкової безпеки в системі національної безпеки. До основних концептуальних засад формування та забезпечення податкової безпеки в системі національної безпеки віднесено: ефективність нормативно-правових засад формування та розвитку податкової безпеки; інституційна спроможність органів державної влади та 
місцевого самоврядування забезпечувати податкову безпеку та спеціально уповноваженого підрозділу для виконання таких функцій; професіоналізація та розвиток кадрів, які працюють в податковій системі; модернізація системи оподаткування 3 метою забезпечення податкової безпеки; комплексна діагностика, головною метою якої $\epsilon$ визначення рівня податкової безпеки; формування дієвих заходів подолання корупції, мінімізації проявів корупції.

У перспективі подальших розвідок передбачається проаналізувати світові моделі формування та забезпечення податкової безпеки в системі національної безпеки держави.

\section{Лimepamypa:}

1. Голіков С. С. Сутність податкової безпеки. Економіка та держава. 2015 . № 9. С. 129-132.

2. Цимбалюк I. О. Податкова безпека в системі фінансової безпеки держави : кол. монографія/ за заг. ред. О. В. Кендюхова. Стратегічне управління начіональним економічним розвитком : монографія : в 2 т. Донецьк : ДВНЗ ДонНТ», 2013. Т. 2. 392 с.

3. Іщенко В. В. Податкова складова фінансової безпеки держави. Вісник економіки транспорту і промисловості. 2012. № 37. С. 35-40.

4. Цвилий-Букланова А. А. Налоговый контроль в системе обеспечения налоговой безопасности государства : автореф. дис. на соискание ученой степени канд. юрид. наук : спец. 12.00.14. Челябинск, 2011. 32 с.

5. Іванов Ю. Б., Бережна Ю. В. Податкова безпека: сутність та умови забезпечення. Економіка розвитку. 2010. № 2 (54). С. 9-11.

6. Податковий кодекс України. URL: https://zakon.rada.gov.ua/laws/show/2755-17\#Text

7. Закон України «Про внесення змін до Податкового кодексу України та інших законів України щодо стимулювання детінізації доходів та підвищення податкової культури громадян шляхом запровадження одноразового (спеціального) добровільного декларування фізичними особами належних їм активів та сплати одноразового збору до бюджету». URL: https://ips.ligazakon.net/document/t211539?an=1

8. Закону України «Про Бюро економічної безпеки України». URL: https://zakon.rada.gov.ua/laws/show/1150-20\#Text

\section{References:}

1. Holikov S. S. (2015), Sutnist podatkovoi bezpeky [The essence of tax security]. Ekonomika ta derzhava - Economy and state, (9): 129-132. [in Ukrainian].

2. Tsymbaliuk I. O. (2013), Podatkova bezpeka v systemi finansovoi bezpeky derzhavy : kol. monohrafiia [Tax security in the system of financial security of the state: col. monograph]. Stratehichne upravlinnia natsionalnym ekonomichnym rozvytkom : monohrafiia - Strategic management of national economic development: monograph : $\mathrm{v} 2$ t. Donetsk : DVNZ DonNT, T. 2. [in Ukrainian].

3. Ishchenko V. V. (2012), Podatkova skladova finansovoi bezpeky derzhavy [Tax component of financial security of the state]. Visnyk ekonomiky transportu i promyslovosti - Bulletin of Transport Economics and Industry, (37): 35-40. [in Ukrainian].

4. Cvilij-Buklanova A. A. (2011), Nalogovyj kontrol' v sisteme obespechenija nalogovoj bezopasnosti gosudarstva : avtoref. dis. na soiskanie uchenoj stepeni kand. jurid. nauk : spec. 12.00.14 [Tax control in the system of tax security of the state: author's ref. dis. for the degree of Cand. jurid. Science: special. 12.00.14], Cheljabinsk. [in Russian].

5. Ivanov Yu. B. \& Berezhna Yu. V. (2010), Podatkova bezpeka: sutnist ta umovy zabezpechennia [Tax security: the essence and conditions of security], Ekonomika rozvytku Development economics, (2) (54). [in Ukrainian]. 
6. Podatkovyi kodeks Ukrainy [Tax Code of Ukraine]. Retrieved from https://zakon.rada.gov.ua/laws/show/2755-17\#Text [in Ukrainian].

7. Zakon Ukrainy «Pro vnesennia zmin do Podatkovoho kodeksu Ukrainy ta inshykh zakoniv Ukrainy shchodo stymuliuvannia detinizatsii dokhodiv ta pidvyshchennia podatkovoi kultury hromadian shliakhom zaprovadzhennia odnorazovoho (spetsialnoho) dobrovilnoho deklaruvannia fizychnymy osobamy nalezhnykh yim aktyviv ta splaty odnorazovoho zboru do biudzhetu» [Law of Ukraine "On Amendments to the Tax Code of Ukraine and other laws of Ukraine to stimulate the deshadowing of income and increase the tax culture of citizens by introducing one-time (special) voluntary declaration of assets belonging to individuals and payment of one-time fee to the budget]. Retrieved from https://ips.ligazakon.net/document/t211539?an=1 [in Ukrainian].

8. Zakonu Ukrainy «Pro Biuro ekonomichnoi bezpeky Ukrainy» ["On the Bureau of Economic Security of Ukraine"]. Retrieved from https://zakon.rada.gov.ua/laws/show/1150-20\#Text [in Ukrainian]. 